\title{
Efektivitas Pelatihan Keterampilan Bimbingan Dan Konseling Untuk Meningkatkan Kemampuan Konselor
}

\author{
Lucia Hernawati $^{1}$, Monika Windriya Satyajati ${ }^{2}$ \\ ${ }^{1,2}$ Fakultas Psikologi UNIKA Soegijapranata \\ 1herna@unika.ac.id \\ ${ }^{2}$ monika@unika.ac.id
}

\begin{abstract}
Abstrak: Perguruan tinggi bukan hanya tempat mahasiswa memperoleh pengetahuan akademik namun juga tempat pembentukan karakter yang cerdas, inovatif, tangguh dan resilien. Salah satu cara pembentukan karakter mahasiswa yang cerdas, inovatif, tangguh dan resilien, melalui pengolahan berbagai masalah yang dialaminya dalam bidang akademik maupun non akademik. Unit Sahabat Psikologi (sabpsi) adalah sebuah unit yang memberi layanan bimbingan dan konseling kepada mahasiswa S1 dan S2 Fakultas Psikologi UNIKA Soegijapranata. Masalah yang dialami mahasiswa semakin bervariasi jenis dan intensitasnya, bukan hanya masalah akademik namun juga masalah yang mengarah pada psikopatologis klinis. Tujuan dari aktivitas pengabdian masyarakat ini untuk meningkatkan pengetahuan dan keterampilan bimbingan dan konseling (konselor) sabpsi agar dapat melayani mahasiswa secara maksimal. Pelatihan ini diberikan selama 4 minggu meliputi pelatihan (1) kepribadian yang terapeutik; (2)psikopatologis klinis (3) psikoedukasi, dan konseling online; (4) konseling kelompok. Pelaksanaan pelatihan dengan frekuensi 1 minggu 1 topik dengan durasi 120 menit secara daring menggunakan platform google meet. Setiap sesi pelatihan diikuti tugas rumah yang didiskusikan pada pertemuan berikutnya. Berdasar pembandingan pretes dan postes diketahui bahwa setelah mengikuti pelatihan, peserta (1)lebih mampu mengarahkan dirinya agar memiliki kepribadian yang terapeutik; (2)lebih memahami psikopatologis klinis; (3) mampu membuat program layanan psikoedukasi dan melaksanakan konseling online; (4)mampu memfasilitasi konseling kelompok.
\end{abstract}

Kata kunci: Pelatihan, konselor, layanan bimbingan konseling, mahasiswa

\begin{abstract}
A university is not only a place for students to gain academic knowledge but also a place for shaping intelligent, innovative, tough and resilient character. One way to build such character is through various problems they experience in both academic and non-academic fields. Unit Sahabat Psikologi (Sabpsi) is a unit that provides guidance and counseling services to undergraduate and postgraduate students of the Faculty of Psychology UNIKA Soegijapranata. The problems experienced by students are increasingly varied in type and intensity, not only academic problems but also problems that lead to clinical psychopathology. The purpose of this community service activity is to increase the knowledge and skills of the sabpsi counsellor in giving guidance and counseling so that they can serve students optimally. This training was given for 4 weeks with these following topics (1) therapeutic personality; (2) clinical psychopathology (3) psychoeducation, and online counseling; (4) group counseling. Online training was conducted every week using gmeet platform. Each training session was followed by homework which would be discussed at the next meeting. Based on the results of the pretest and posttest, it was revealed that after participating in the training, participants (1) were more able to direct themselves to have a therapeutic personality; (2) better understood clinical psychopathology; (3)were able to make psychoeducation services program and carry out online counseling; (4) were able to facilitate group counseling.
\end{abstract}

Keywords: training, counselors, counseling services, students 


\section{PENDAHULUAN}

Dalam mengoptimalkan performa akademik mahasiswa di Fakultas Psikologi, diperlukan adanya layanan konseling dan pendampingan secara intensif bagi mahasiswa. Unit Konseling Sahabat Psikologi merupakan unit khusus yang dibentuk untuk memberikan pendampingan berupa bimbingan dan konseling untuk membantu kelancaran mahasiswa dalam menyelesaikan Pendidikan di jenjang perguruan tinggi. Pada awalnya, unit Sahabat Psikologi dibentuk untuk memberikan pendampingan psikologis bagi mahasiswa yang mengalamai kesulitan dalam mengerjakan skripsi, kesulitan dalam beradaptasi dengan proses pembelajaran selama kuliah. Masalah non-akademik pun juga menjadi keluhan mahasiswa. Dewasa ini, mulai muncul masalah terkait kemampuan mahasiswa dalam mengelola diri, misalnya dalam berhubungan dengan lingkungan sosial, atau prokrastinasi dalam mengerjakan tugas, hingga masalah yang mengarah pada psikopatologi klinis, misalnya psikosomatis, hingga depresi. Namun sejalan dengan dinamika masalah yang dialami mahasiswa, unit sahabat psikologi banyak membantu mahasiswa yang bergumul dengan permasalahan diri sendiri dalam berhubungan dengan lingkungan sosial (orangtua-temanpacar) hingga masalah yang mengarah pada psikopatologi klinis, misalnya psikosomatis hingga depresi.
Data layanan konseling di Unit Sahabat Psikologi dari bulan April hingga Oktober 2020 menunjukkan bahwa dari 43 klien yang berkonsultasi, sebanyak $74 \%$ justru berkonsultasi karena adanya masalah psikologis mulai dari hubungan dengan keluarga, hubungan dengan pacar, teman, hingga permasalahan emosi dan bahkan adiksi. Sebesar $16 \%$ klien berkonsultasi karena adanya masalah akademik seperti tujuan awal Sahabat Psikologi. Contoh masalah yang dihadapi adalah kesulitan dalam mengerjakan skripsi atau kesulitan mengikuti proses perkuliahan. Di sisi lain, terdapat $5 \%$ yang berkonsultasi karena adanya perpaduan masalah psikologis dan akademis, dan terdapat 5\% lain yang berkonsultasi terkait karir atau pekerjaan, baik itu pertimbangan mengenai pekerjaan paruh waktu saat ini, atau konsultasi mengenai keinginan karir di masa depan. Dominannya kasus psikologis non akademis yang dihadapi membuat para konselor Sahabat Psikologi memerlukan adanya pembekalan khusus

\section{PERUMUSAN MASAlah}

Perguruan tinggi bukan hanya tempat mahasiswa mendapatkan pengetahuan secara akademis namun juga non akademis. Perguruan tinggi harus menyiapkan kurikulum yang sesuai dengan program studi masing-masing juga menyiapkan layanan 
bimbingan dan konseling yang dapat membekali mahasiswa agar berprestasi dalam bidang akademik dan mampu belajar untuk hidup (Gysbers \& Henderson, 2012); (Astarini, Nirwana, \& Ahmad, 2016).

Hal serupa diungkapkan Adebowale (2011) bahwa pendidikan adalah landasan dasar bagi pengembangan sebuah bangsa. Karena dalam pendidikan bukan hanya disampaikan materi-materi pengetahuan namun juga membentuk karakter. Khususnya dalam pendidikan tinggi perguruan tinggi selain berkewajiban menyampaikan berbagai materi pengetahuan, juga harus membantu mahasiswa yang sedang bergulat dengan masalah pribadi, masalah akademik, dan masalah umum lainnya.

Perguruan tinggi dengan semua fakultas yang dimiliki bertanggung jawab mengantarkan seluruh mahasiswa agar mendapat tantangan dan kesempatan untuk memulai hidupnya menjadi individu utuh yang memiliki kehidupan yang baik. Untuk ini perguruan tinggi/fakultas harus membantu mahasiswa agar lebih menyadari kediriannya, tujuan hidup dan passion nya. Perguruan tinggi harus membantu mahasiswa mengembangkan potensinya agar dapat hidup lebih nyaman, sejahtera secara psikologis, bahagia (well being khususnya psychological well being). Selanjutnya psychological well being disingkat PWB (Pingree \& Harward, 2014); (Yuliani, 2018).
Fakultas Psikologi UNIKA Soegijapranata memiliki unit sahabat psikologi yang memberikan layanan bimbingan dan konseling pada mahasiswa S1 dan S2. Hal ini sejalan dengan pemikiran (Adegoke dalam Adebowale, 2011) yang menyebutkan bahwa perguruan tinggi/fakultas harus memiliki unit layanan bimbingan dan konseling yang dapat membantu mahasiswa memahami potensi diri dan memaksimalkannya, serta menyelesaikan berbagai masalah yang dimilikinya. Lebih lanjut Pratama \& Suharni (2017) menyebutkan bahwa layanan bimbingan dan konseling di perguruan tinggi selain bertujuan untuk memfasilitasi mahasiswa agar dapat mengefektifkan kegiatan belajarnya juga memberi arah bagi tercapainya kesuksesan sepanjang hayat, baik pada rentang tujuan jangka pendek, menengah maupun jangka panjang. Dengan demikian pelaksanaan layanan bimbingan dan konseling di perguruan tinggi melibatkan banyak pihak, bukan hanya menjadi tugas konselor namun pihak pengelola universitas, fakultas, tenaga adiministrasi, mahasiswa, orangtua, dan masyarakat (Afdal, 2015).

Sejalan dengan semakin beragam masalah dan intensitas permasalahan mahasiswa, bukan hanya dalam hal akademik namun juga pergumulan pribadi yang melibatkan upaya untuk menemukan jati diri, mengontrol emosi, membuat strategi 
hidup sehat holistik, menggalang relasi harmoni dengan orangtua-pacar-teman, berdamai dengan keadaan yang tidak diinginkan. Lebih detail lagi, dalam keseharian konselor sahabat psikologi saat memberi layanan pada mahasiswa mulai banyak menemukan permasalahan psikologis yang semakin menunjukkan indikasi klinis. Adanya riwayat kekerasan seksual, permasalahan psikosomatis, bahkan juga adanya adiksi terhadap pornografi menjadi topik yang mulai lebih sering diceritakan oleh mahasiswa pada konselor di unit Sahabat Psikologi. Dinamika masalah mahasiswa yang semakin rumit dibandingkan awal pendirian unit sahabat psikologi membuat perlunya pembekalan pengetahuan dan keterampilan konselor unit sahabat psikologi dalam hal bimbingan dan konseling yang meliputi (1) kepribadian yang terapeutik; (2)psikopatologis klinis (3) psikoedukasi, dan konseling online; (4) konseling kelompok agar dapat melayani mahasiswa dengan maksimal

\section{METODOLOGI}

Pelatihan dilaksanakan selama 4 minggu, dengan frekuensi 1 minggu dengan 1 topik pelatihan disampaikan kepada peserta dan durasi 120 menit tiap sesi pelatihan. Sebelum mengikuti pelatihan, peserta diminta mengisi informed consent yang berisi kesanggupan peserta mengikuti pelatihan secara keseluruhan mulai dari awal hingga akhir dengan penuh kesungguhan serta berkomitmen untuk mengaplikasikan semua materi yang diperoleh untuk memberi pelayanan konseling yang efektif pada mahasiswa selama 1 tahun.

Apapun topik materi pelatihan yang disampaikan adalah sebagai berikut:

"Kepribadian Terapeutik". Topik materi ini disampaikan agar peserta memahami bahwa dirinya adalah alat utama yang dapat dipakai untuk menciptakan kondisi konseling yang kondusif. Dengan demikian perlu dipahami karakteristik kepribadian terapeutik konselor dan perlu melakukan self-evaluation dan mengupayakan setidaknya memiliki kepribadian mendekati karakteristik kepribadian terapeutik konselor yang seharusnya; (2) "Berhadapan dengan Klien yang Memiliki Permasalahan Klinis". Materi ini disampaikan agar peserta memahami klasifikasi gangguan psikologis berdasar DSM V dan mampu menggalang komunikasi dalam memeriksa status mental konseli; (3) "Konseling Online dan Psikoedukasi". Topik ini diberikan agar peserta memahami karakteristik dan teknik-teknik yang digunakan pada konseling online untuk membawa konseli pada insight dan tujuan penyampaian materi psikoedukasi agar peserta dapat memahami bahwa aspek preventif dalam bentuk penyuluhan psikologis perlu diberikan pada mahasiswa 
serta mampu merancang program psikoedukasi untuk mahasiswa;

"Konseling Kelompok". Tujuan penyampaian materi ini agar peserta memahami karakteristik, tahap-tahap dan teknik-teknik yang dipakai dalam konseling kelompok dan dilanjutkan dengan praktek konseling kelompok. Diakhir penyampaian tiap topik, peserta diberi tugas rumah yang memberikan kesempatan untuk mempraktekkan apa yang telah dipahami pada perilaku riil. Tugas rumah ini disharringkan dan dibahas pada sesi selanjutnya.

Pelatihan dilaksanakan mulai tanggal 17 November 2020 hingga 8 Desember 2020. Diikuti seluruh konselor unit sahabat psikologi yang berjumlah delapan orang. Dilaksanakan secara daring dengan platform google meet. Peserta diminta mengisi pretes sebelum pelatihan dimulai dan postes setelahmateri pelatihan diberikan secara keseluruhan. Selanjutkan pretes dan postes dibandingkan untuk mengetahui efektifitas pemberian pelatihan bimbingan dan konseling pada peserta.

\section{PEMBAHASAN}

Konselor adalah seseorang yang professional dan terlatih yang membantu konseli dalam menyelesaikan masalahnya (Corey, 2013). Konselor unit sahabat psikologi mendapat berbagai pelatihan bimbingan dan konseling secara bertahap. Hal ini sesuai dengan pendapat (Samuel, 2015) bahwa konselor dalam menjalankan tugasnya sebagai fasilitator, motivator, guru bagi konseli dalam konseling harus terus belajar untuk meningkatkan pengetahuan berbagai pendekatan dan teknik konseling agar dapat melayani konseli secara maksimal. Dengan demikian perlu diberikan berbagai pelatihan bimbingan dan konseling untuk konselor.

Materi kepribadian terapeutik diberikan pada pelatihan ini karena konselor harus memahami bahwa kehadiran fisiknya termasuk didalamnya kepribadiannya adalah alat yang utama untuk menciptakan konseling yang kondusif. Kepribadian konselor setidaknya mendekati kepribadian terapeutik yang seharusnya (Corey, 2013).

Dinamika masalah mahasiswa bukan hanya masalah akademik namun memiliki kecenderungan klinis psikopatologis sehingga kepada konselor perlu diberikan materi tentang klasifikasi gangguan psikologis berdasar DSM V agar mampu menggalang komunikasi dalam memeriksa status mental konseli (Halgin \& Whitbourne, 2009)

Jenis konseling online sangat efektif dilakukan manakala konseling tatap muka tidak bisa dilakukan seperti sekarang ini karena pandemic covid 19. Untuk pelaksanaan konseling online ada teknik- 
teknik khusus yang harus diketahui konselor (Bloom \& Walz, 2004). Untuk itu topik "konseling online" perlu dibahas dan didiskusikan dengan konselor. Demikian pula pemberian penyuluhan dalam bentuk psikoedukasi (perpaduan antara psikoterapi dan edukasi) sangat bermanfaat untuk memberi penyuluhan pada mahasiswa sebagai tindakan preventif. Dengan cara ini diharapkan masalah yang potensial dialami mahasiswa dapat diminimalkan (Supratiknya, 2011). Dengan alasan ini kepada konselor diberikan materi psikoedukasi

Topik terakhir dari pelatihan ini adalah konseling kelompok. Materi ini dianggap penting karena jenis konseling kelompok efektif membantu mahasiswa karena dalam konseling kelompok mahasiswa saling menceritakan pengalaman dan saling memberi dukungan. Disamping itu mahasiswa mempunyai kesempatan untuk melihat sebuah permasalahan dari berbagai sudut pandang dan dalam waktu yang relative singkat dapat membantu 6-8 orang sekaligus (Corey,2012)

Pembandingan antara pretes dan postes menunjukkan bahwa pelatihan bimbingan dan konseling telah mampu meningkatkan pengetahuan dan keterampilan peserta, sehingga besar kemungkinan dapat memberi layanan kepada mahasiswa secara maksimal. Hal ini sesuai dengan pendapat
(Corey, 2013) bahwa konseling adalah ilmu pengetahuan dan kreativitas membantu memecahkan masalah. Konselor diberi berbagai pengetahuan tambahan tentang bimbingan dan konseling, selanjutnya konselor akan mengembangkan akumulasi semua pengetahuannya sendiri.

\section{PENUTUP}

Unit Sahabat Psikologi fakultas Psikologi - UNIKA Soegijapranata adalah unit layanan bimbingan dan konseling untuk membantu mahasiswa S1 dan S2 dalam menyelesaikan masalahnya. Masalah yang dimiliki mahasiswa semakin rumit. Bukan hanya masalah akademik namun juga pergumulan diri yang membuatnya tidak dapat menunjukkan performa akademik yang maksimal.

\section{Konselor Unit Sahabat Psikologi} perlu mendapat pembekalan secara berbagai pendekatan dan teknik konseling untuk menambah pengetahuan dan keterampilan dalam memberikan layanan bimbingan dan konseling pada mahasiswa

\section{Simpulan}

Pemberian pelatihan kepada konselor unit sahabat psikologi dengan materi 1) kepribadian yang terapeutik; (2)psikopatologis klinis (3) psikoedukasi, dan konseling online; (4) konseling kelompok berhasil meningkatkan penyadaran peserta tentang karakteristik kepribadiannya yang 
Patria : Jurnal Pengabdian Kepada Masyarakat

ISSN : 2656-5455 (media online) Vol. 3 | No. 2 September 2021

bisa jadi menghambat untuk kelangsungan proses konseling yang kondusif. Dan berupaya memperbaiki diri agar menjadi konselor yang memiliki karakteristik kepribadian yang setidaknya mendekati kepribadian terapeutik; mampu memahami masalah klinis, termasuk didalamnya klasifikasi gangguan berdasar DSM V dan dapat menggalang komunikasi untuk melakukan pemeriksaaan status mental; mampu memahami bentuk-bentuk layanan psikoedukasi serta merancang program layanan psikoeduaksi yang dapat diberikan pada mahasiswa S1 dan S2; mampu memahami karakteristik, prosedur dan teknik- teknik konseling yang dipakai dalam konseling online serta dapat mempratekkannya dalam konseling riil.

\section{Saran}

\section{Bagi Fakultas Psikologi UNIKA \\ Soegijapranata}

Fakultas mempunyai program yang dapat memberikan berbagai pelatihan bimbingan dan konseling pada konselor unit sahabat psikologi agar secara berkala konselor dapat terus meningkatkan pengetahuan dan keterampilannya

\section{Bagi Konselor}

Konselor dapat mengaplikasikan semua pengetahuan dan keterampilan yang sudah diberikan pada pelatihan agar mampu memberi layanan bimbingan dan konseling yang maksimal pada mahasiswa

\section{DAFTAR PUSTAKA}

Adebowale, T. A. (2011). "Perceived Availability of Guidance and Counseling Servis among Tertiary Institute Students in Selected South-West University in Nigeria". Life Psychology, 19 (1), hlm. 360-374.

DOI: 10.4314/ifep.v19i1.64608

Afdal (2015). "Kolaboratif: Kerangka Kerja Konselor Masa Depan". Jurnal Konseling dan Pendidikan, 3(2), hlm1-7. ISSN Cetak: 2337-6740 - ISSN Online: 2337-6880. Diperoleh dari http://jurnal.konselingindonesia.com

Astarini, D., Nirwana, H., Ahmad, R. (2016). "Hubungan antara Konsep Diri Sosial, Persepsi Siswa tentang Dukungan Sosial Orangtua, dan Teman Sebaya dengan Komunikasi Interpersonal Siswa dan Implikasinya terhadap Pelayanan Bimbingan dan Konseling". Konselor 5(4), hlm 247-257. ISSN: Print 14129760 - Online 2541-5948. Diperoleh dari http://ejournal.unp.ac.id/ index.php/konselor

Bloom, J.W., Walz, G.R, 2004, Cybercounseling \& Cyberlearning. An Encore, US: CAPS Press

Corey, G. (2012). Theory and Practice of Group Counseling, USA: Brooks/Cole

Corey, G. (2013). Theory and Practice of Counseling and Psychoterapy, Australia: Brooks/Cole.

Gysbers, Norman, C., \& Henderson, Patricia. (2012). Developing \& Managing Your School Guidance \& Counseling Program, USA: American Counseling Association.

Halgin, R.P., \& Whitbourne, S.K. (2009). Psikologi Abnormal (terjemahan). Jakarta:Salemba Humanika

Pingree, Harward. (2014). Bringing Theory to Practice. The Psychological Well 
Patria : Jurnal Pengabdian Kepada Masyarakat

ISSN : 2656-5455 (media online) Vol. 3 | No. 2 September 2021

Being and Flourishing of Students, Liberal Education

Pratama, B., D. \& Suharni. (2017). Layanan Bimbingan Dan Konseling Dalam Mengatasi Siswa Underachiever. Jurnal Ilmiah Counsellia, 7(1), hlm 1-10. PISSN 2088-3072 E-ISSN 2477-5886. Diperoleh dari e-journal.unipma.ac.id.

Samuel, T \& Gladding. (2015). Konseling Profesi yang Menyeluruh, Jakarta: Indeks

Supratiknya, A. (2011). Psikoedukasi, Yogyakarta: penerbit Universitas Sanata Darma

Yuliani. I. (2018). "Konsep Psychological Well-Being Serta Implikasinya Dalam Bimbingan Dan Konseling". Journal of Innovative Counseling : Theory, Practice \& Research, 2 (2), hlm 7-12. ISSN (Print): 2548-3226 .ISSN (Online): 2580-7153. Diperoleh dari http://journal.umtas.ac.id/ index.php/ innovative counseling 